\title{
THE INFLUENCE OF THE TRACES OF ART ON THE TEXTURE OF THE CITY
}

\author{
Asuman Soylu ${ }^{25}$
}

\begin{abstract}
The city is a living space in which the social, political, administrative and economic spheres exist for all citizens. The concept of city; It contains all the dimensions surrounding and influenced by the urban people. By living in the formation of urban intelligence, visual learning also has an important place. The cities or parts of the city, which have been preserved and repaired and, if necessary, renovated in accordance with this urban fabric, are becoming settlements or regions that provide the identity of the city and describe the difference of urbanization. In this phase, "urban design" is also an integral part of urban protection. The integration of human settlements with new urban meeting spaces and the support of a quality new architecture enable the social tension to be reduced and to be met in common pavilions. Urban History- Urban identity-urban culture, urban texture reflects the people living in the city. Cities are defined by their cultural assets. Just as in the case of the Istanbul mosques, the Ankara Antkabir, the Paris Eiffel Tower, the New York Statue of Liberty, the Egyptian Pyramids, the city stands out with its unique architectural element or spatial arrangement. Living a city; it is the history, culture and art of the city. In tourism, there is also a growing interest in historical, educational, cultural, artistic and travel routes. It is necessary to identify the sources that allow tourism in the cities. While emphasizing the preservation of old tact in the declaration; how to get artistic touch and how to bring it to tourism.
\end{abstract}

Keywords: Urban texture, identity, culture, artistic traces, touristic places

\section{CITY-URBANIZATION}

Cities are the living spaces of the individuals. Cities are the places where production and consumption items are realized, where they plan to spend the entire time for the living, working and recreation functions, growing in rural areas [1].

The concept of city has a meaning beyond just being a physical space and population definition. At the same time, the city's work and research are being carried out by many different disciplines, since it expresses the process of radical structuring. For this reason, the city is a multidimensional and unbounded study area, and as the city is trying to explain a single definition, it is very difficult for the city to be a multidimensional element and to change society from different times. When the definitions are combined, the city has become a place where non-agricultural production is made, where control functions are gathered and have reached a certain level of size, heterogeneity and integration levels.

${ }^{25}$ Lecturer, Department of Painting, Faculty of Fine Arts, Akdeniz University, Antalya, Turkey, email: asumansoy@gmail.com 
The urbanization; it is the natural outcome of the urbanization process, which, together with the environment, technological and economic organization, enables individuals to integrate with society and leads to the settlement of cultural items.

\section{CITY IDENTITY}

Cities are separated from each other by showing various character traits in terms of natural conditions, structures and humanity. Everything that distinguishes one city from the other and differs from others is its identity. ${ }^{26}$ As urbanization, urban transformation and tourism come to the agenda, the identity of the city is at the forefront and it has an impact on the planning and implementation of the activities to be carried out. Today, the disappearance of urban identities and the emergence of mutually resembling tissues are not only a cultural problem, but also have economic, social and psychological consequences. When we look at the cities lacking identity, it is observed that these cities are not satisfied with their urban spaces, physical conditions and the experience formed within them. It is seen that the strong, identifiable cores of these cities had been carried out in certain periods and could not have been carried out limitedly and daily well [2].

\section{CITY CULTURE}

The concept of culture explains why people are similar or unequal to each other and why they have changed. In contrast to different definitions, the way culture meets the needs of a society can be regarded as an organic and volatile entity formed by institutions and groups, beliefs and traditions. While man reproduces nature, he also produces himself.

\section{URBAN FABRIC / URBAN TEXTURE}

The remaining settlements and remains from past civilizations constitute historical circulation. In today's conditions in which traditional values are rapidly destroyed; zoning changes, population growth, industrialization, and other factors cause the degradation of the historical environment of the cities and the confusion of identity. These distortions observed in the history of the cities have started a process which is impossible and irreversible in the historical environment [3]. The end result is a process that is not possible to protect cities as prestige areas. As a result, the historic city textures, which must be protected as prestige areas of cities, are transformed into decaying areas. However, the historical city textures are special areas that are important 
contributors to the urban environment, so long as they are able to maintain their viability and maintain a harmonious coherence with the development and change of the city.

\section{HISTORICALL PROCESS; FIRST CITY - CITY PLAN - LANDSCAPE ARCHITECTURE - CITY ICONS}

According to the scientists, the first cities to be founded are Greek and Roman cities. But the prevailing opinion is that the first cities appeared in Mesopotamia, MesoAmerica and the Nile, Indus and Yellow River. In the kingdoms gathered under the name of Mesopotamian civilizations, there are first examples of urban plan (Çatalhöyük-Hattuşaş), landscape architecture (The hanging gardens of Babylon), religious architecture (Ziggurats) [4]. It can be said that Anatolia has experienced a unique evolutionary process in terms of urban history. The first settlement that can be considered as the beginning of city life is Çatalhöyük on the Konya Plain in Turkey. (5700-6700 B.C.) Çatalhöyük, believed to have 500-600 inhabitants, was the most important 'urban core' on earth. The city plan was seen in Hattusas, the capital of the Hittites, who settled in Anatolia in early 2000 BC.

Almost all of today's art is found in Sumerian culture. According to Sumerian belief, before people were created, gods made cities and appointed a chief god to govern them. And art has taught people by gods. II. Nabukadanaezar have built "hanging gardens" in 605-562 BC for his wife Semiramis in Babylon was accepted as a magnificent palace garden. In this park; facilities, sightseeing spots, entertainment spots have also emerged in this civilization for the first time. These gardens can be shown as the first examples of landscape architecture [6].

In this period, the symbol of cities among the temples in almost every city, "Ziggurats" are rising. The Ziggurat is the temple tower, which resembles the pyramids of the former Mesopotamian valley and the terrace of Iran. Multipurpose Ziggurats contain important artistic and architectural items [4]. Illustration of Ziggurat, illustration of Çatalhöyük urban plan, illustration of Hanging Gardens of Babylon and Hattuşaş urban plan are given in Fig. 1. 


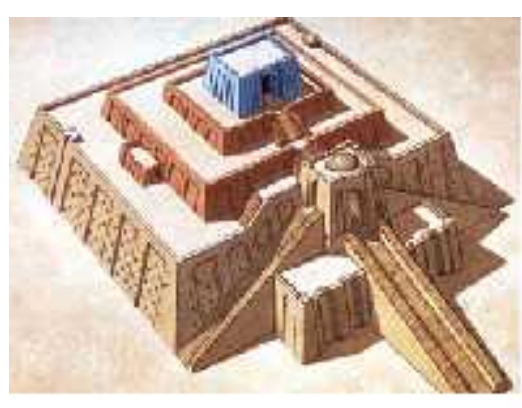

a

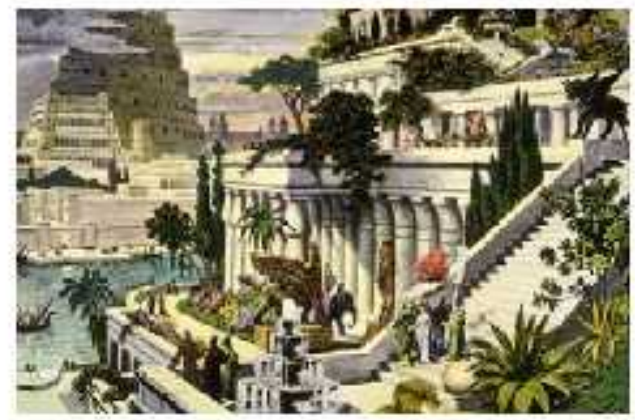

v

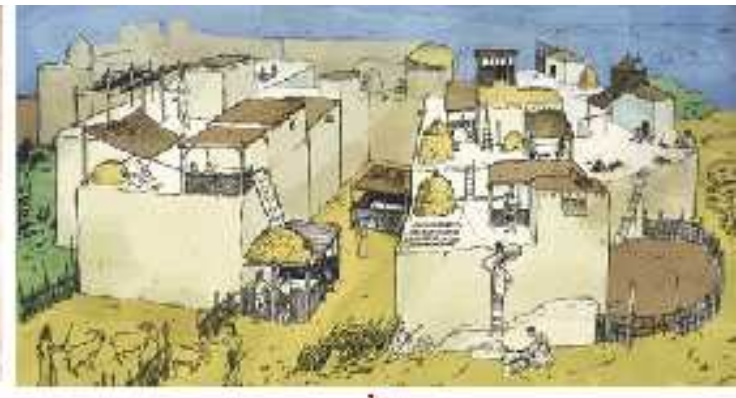

b

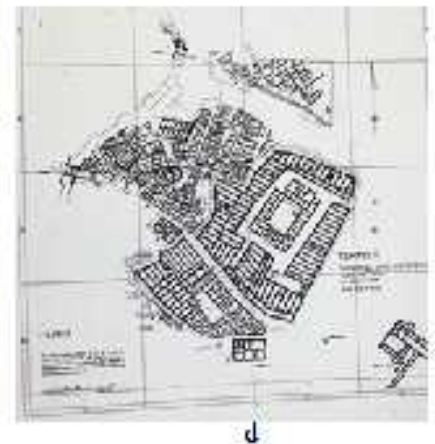

Fig. 1: a. Illustration of Ziggurat, b. Illustration of Çatalhöyük urban plan, c. Illustration of Hanging Gardens of Babylon, d. Hattuşaş urban plan

\section{URBAN TOURISM AND ART}

Urban tourism can be defined as the development of different types of tourism and its participation in the tourism sector according to the qualities of the cities, the resources and values they possess.

For cities, tourism is an important factor with the input, the employment opportunities and the social-cultural interactions it provides.

The population movement based on the source of development such as tourism and commerce and thus the increase in the structure and the increase of the living standards are causing the increase of the living standards. The factors affecting each other are the ones that must be balanced in urban development. In this context, it is important to protect the potentials and resources of cities in accordance with urban identity.

Travel to urban areas, recognition of urban cultures and interest in urban recreational activities are increasing. In this context, urban spaces and tourism relations have gained importance. Street art examples are given in Fig. 2. 

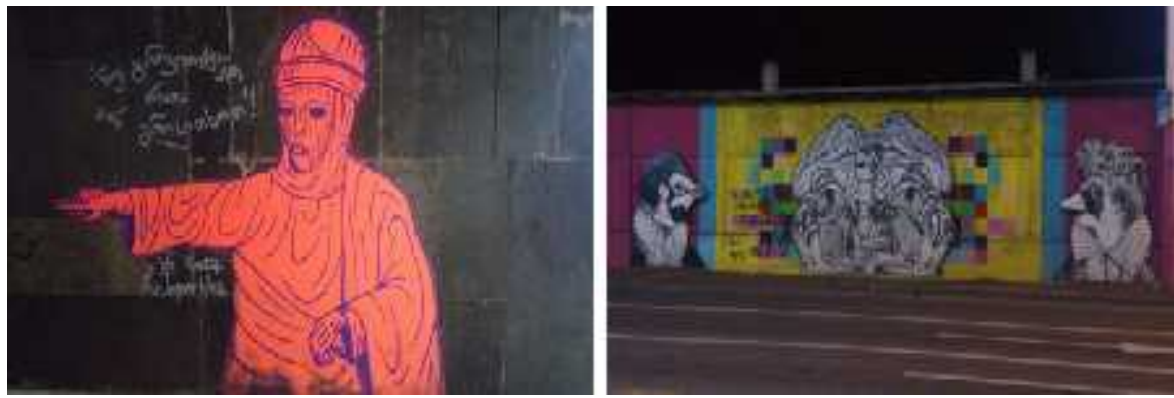

Fig. 2: Street art examples: Tbilisi/Georgia(left), Zagreb/Croatia(right)

Source: Photographs were taken during cultural visits in Tbilisi-Georgia and Zagreb-Croatia.

\section{FEATURES WHICH ARE UTILIZING URBAN TOURISM IN URBAN AREAS}

- Facilities and structures related to activity places, concert halls, exhibition areas, museums, art galleries, sports organizations and special events.

- Entertainment elements, ancient-antique cities-structures, monumental buildings, monuments, ports, historic urban dwellings, parks and green spaces, special structures

- Social-cultural elements, language, folklore, local activities, traditional activities

- Trade, shopping, special programs and events can be counted.

\section{SOURCES TO PROVIDE TOURISM IN CITIES}

- Historical and cultural values

- Religious, faith and places that are made important from the traditional point of view

- Fair and Exhibition activities, Congress.

- Water resources (Lake, Sea, River etc.)

- Festivals and local special events, celebrations

- Culture-Arts, entertainment, sports activities

- Local shopping can be classified as trade opportunities [1]

Local methods in cities; art and artistic festivals to bring together the arts. At the same time, introducing the people of city to art, city culture, city to introduce the tourists. For example, I can show the international festival performed by Kadikoy municipality in Turkey. The wall paintings that the artists made in the scope of the festival changed the silhouette of the city. The artists of the festival took Kadiköy, Istanbul, Turkey to reflect the different cultures and to bring an urban look into the city. Street art samples (Wall art) of Kadıköy are given in Fig. 3. 


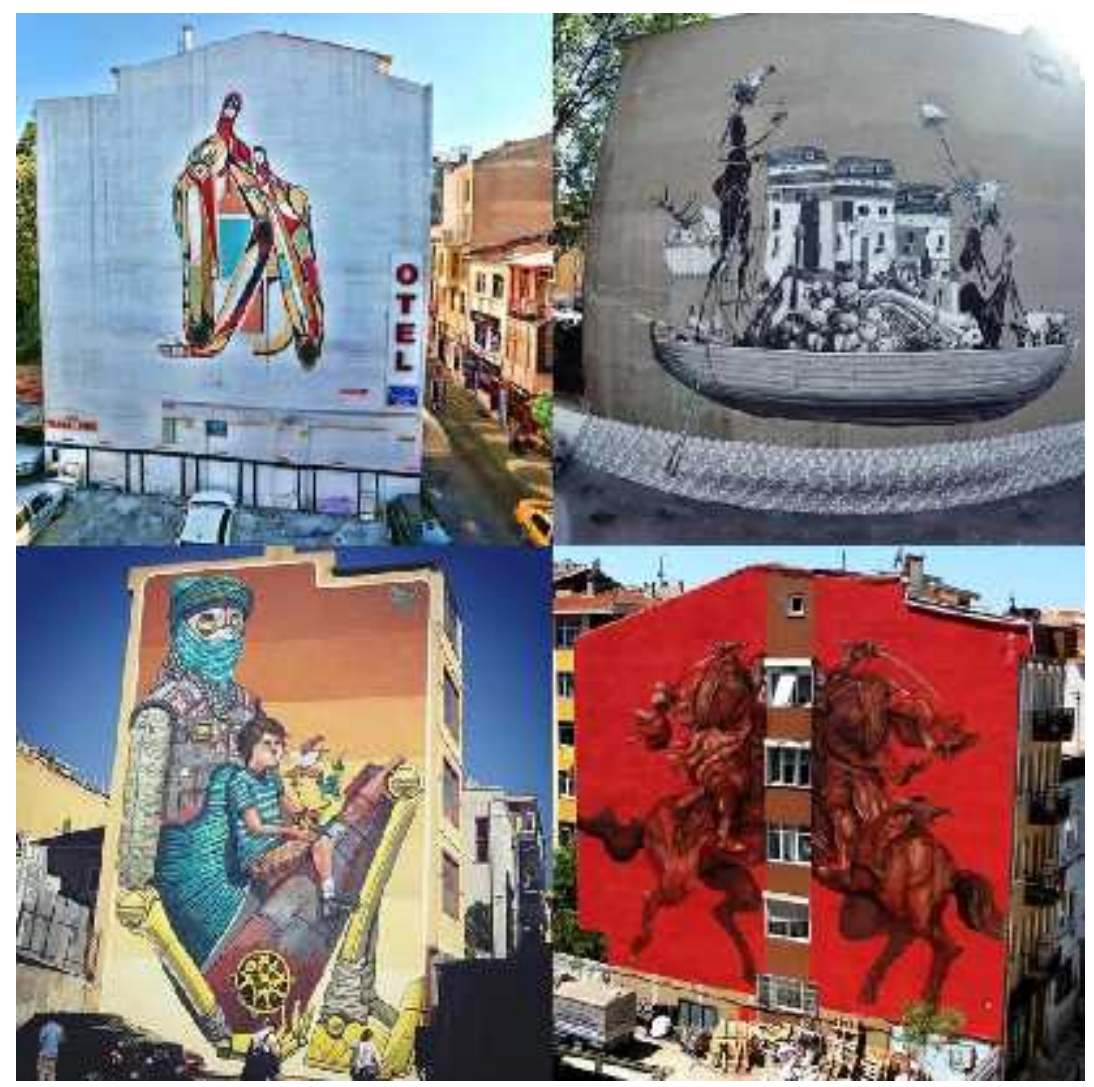

Fig. 3: Street art samples (Wall art) of Kad1köy, Istanbul, Turkey Source: 8. The Magger, 2014. Kadıköy Street Art, Yel değirmeni,

The DUMBO Arts Festival was a multi-site celebration of the arts, bringing innovative and challenging artwork to a diverse audience and providing a career-making platform for artists from around the world. Dumbo festival, held in new york, and the works of the artists meet people on the streets. Children and adults are sometimes involved in the construction of works. Other than that, graffities and moss art can be considered as artistic traces seen in urban areas. Arts performances of DUMBO Festival are given in Fig. 4.
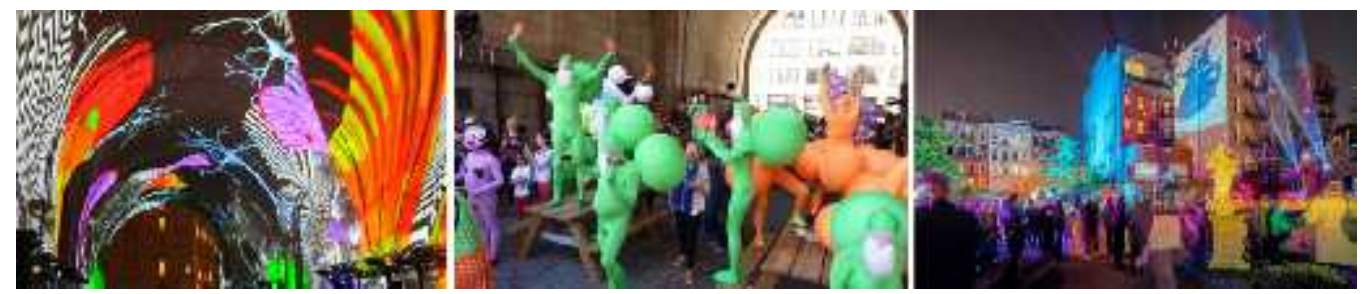

Fig. 4: Arts performances of DUMBO Festival

Source: Schulz, D., 2014. Dumbo Arts Festival, Multiple Brooklyn Locations, 


\section{SUGGESTIONS}

Urban tourism in the world; culture-arts can be categorized as resources that allow tourism in urban areas or as resource elements. To increase the visibility of the artistic traces in the city, art improves and stimulates urban tourism. This is another way of seeing tourists as artisans and tourists. In order to modernize their own culture, it is necessary to include local artists in the creation of artworks. It is important to make a living art.

\section{CONCLUSION}

It is necessary to determine the characteristics of the cities, which have their own unique and tourist attractions, and to bring them to the foreground and gain tourism. In this context, it is important that the assets forming the image of the city are introduced effectively in international and local government-promotional bodies.

The cities, historical buildings, green spaces, ancient cities, cultural places, museums, artworks (such as sculptures, wall paintings, mosaics, etc. artistic traces) and festivals and fields that make up the historic texture of the cities increase the tourism potential of the cities. a product diversification in this direction; tourism movements and incomes will spread all over the world. The artistic visible traces contributing to the city's image contribute to the tourism image of the cities, as well as to the cultural and natural resources as well as tourism.

In addition to this, the increase of the arts in the cities and the fact that the art is intertwined with the city, the tourism potential of the cities will be considerable. However, it is very important that the city and art are compatible with each other. It is very important that the elements of modern art that are applied are in the direction of developing the historical and cultural existence of the city. In other words, it is necessary to investigate the historical and cultural structure of the city before the application of art. Otherwise, the applied works and thoughts will become grotesque. Therefore, the type of art and its method of application should be well thought out and investigated.

At the same time, the art that we can characterize as a supporting element of tourism activities should be accessible by the visitors and locals. This is a reason why urban culture and urban texture are intertwined. So, art should be an element that associates people, cities and art, and makes sense of this association.

\section{REFERENCES}

1. Erdoğan, E., Aklanoğlu, F., 2008. Tourism, Cities and Change: Mardin Example. Second Tourism and Architecture Symposium, Antalya,Turkey, 167. 
2. Oğurlu, ., 2014. Environment - City Image - City Identity - A Perspective On Culture Interactions. Istanbul Commerce University, Journal of Science, 13, 275-293.

3. Özaltın, O., Gül, A., 2006. The Importance of Orienteering in the Scope of Recreation and Tourism and Analysis of the Situation in Turkey, Tourism and Architecture Symposium: Antalya, Turkey, 264.

4. History on the Net, 2017. Ziggurats and Templates in ancienct Mesopotamia, https://www.historyonthenet.com/ziggurats-and-temples-in-ancient-mesopotamia,

5. Crystalinks, 2017.Ziggurats, http://www.crystalinks.com/ziggurat.html

6. Mezopotamya, 2003. Hattuşaş Maps, http://mezopotamya.tripod.com/Hattusas-Haritalari.html

7.Winters, R., 2015. The Magnificent Constructions of King Nebuchadnezzar II, http://www.ancient-origins.net/history-famous-people/magnificent-constructions-kingnebuchadnezzar-ii-003609

8. The Magger, 2014. Kadıköy Street Art, Yel dĕgirmeni, https://www.themagger.com/yeldegirmeni-kadikoy-sokak-sanati

9. Schulz, D., 2014. Dumbo Arts Festival, Multiple Brooklyn Locations, https://www.6sqft.com/new-york-festival-of-light-is-illuminating-dumbo-startingtomorrow-night

10. Agenda New York, 2013. New York Festival of Light Is Illuminating DUMBO Starting Tomorrow Night, https://agendanewyork.wordpress.com/tag/dumbo-artsfestival 